\title{
Cognitive-motivational predictors of epistemically unwarranted bellefis
}

\author{
Peter Halama \\ Centre of Social and Psychological Sciences, Slovak Academy of Sciences \\ Bratislava, Slovakia
}

\section{Introduction}

- The epistemically unwarranted beliefs are defined as those types of beliefs, which are outside the totality of evidence and

knowledge that is available to human knowledge seekers (Lobato et al., 2014).

- Among others, they include conspiracies, paranormal beliefs and pseudoscience beliefs.

- The previous research suggested that cognitive processes (e.g., analytical thinking) can play a certain role in the acceptance of such beliefs (Swami et al., 2014).

\section{Method}

- Sample

- 801 participants (391 males, mean age 42.6 years) recruited from online panel of a research agency in Slovakia.

\section{- Measures}

- The Epistemologically Unfounded Beliefs Scale (Halama 2018) for measuring beliefs in conspiracies (e.g. pseudoscience and paranormal phenomena)

- Personal Need for Structure (Neuberg \& Newsom, 1993) measuring individual differences in the preference for simple cognitive structure

- Need for Cognition Scale-6 (Lins de Holanda Coelho et al., 2018) measuring individuals' tendency to engage in and enjoy effortful cognitive activity

- Brief version of Need for Closure Scale (Roets \& Van Hiel, 2011) measuring the desire to have answers to one's questions and the desire to avoid confusion and ambiguity. It consists of five facets: preference of order, preference for predictability, need for decisiveness, discomfort with ambiguity, and closedmindedness.

\section{Aim of the study}

- The current study focuses on the specific cognitive motivation variables representing motivational tendencies toward the preference of specific ways of dealing with cognitiveinformational tasks and their relationship to epistemically unwarranted beliefs

\section{Results}

Table 1 The results of three multiple regression analyses (standardized betas) with cognitive-motivation variables as predictors and epistemically unwarranted beliefs as dependent variables

\begin{tabular}{|l|c|c|c|}
\multicolumn{1}{|c|}{ Predictors } & $\begin{array}{c}\text { Conspiracy } \\
\text { beliefs }\end{array}$ & $\begin{array}{c}\text { Pseudoscience } \\
\text { beliefs }\end{array}$ & $\begin{array}{c}\text { Paranormal } \\
\text { beliefs }\end{array}$ \\
\hline $\begin{array}{l}\text { Personal need for } \\
\text { structure }\end{array}$ & -.08 & $-.20^{\star \star}$ & $-.11^{\star}$ \\
\hline Need for cognition & -.06 & $-.15^{\star \star}$ & $-.09^{\star}$ \\
\hline Need for closure & $.13^{\star}$ & $.18^{\star *}$ & $.15^{\star *}$ \\
\hline $\mathbf{R}^{2}$ & .013 & .045 & .023 \\
\hline
\end{tabular}

Note. ${ }^{*} p<=.05,{ }^{* *} p<=.01$

Table 2 The results of three multiple regression analyses (standardized betas) with facets of need for closure as predictors and epistemically unwarranted beliefs as dependent variables

\begin{tabular}{|l|c|c|c|}
\hline \multicolumn{1}{|c|}{$\begin{array}{c}\text { Need for closure } \\
\text { facets }\end{array}$} & $\begin{array}{c}\text { Conspiracy } \\
\text { beliefs }\end{array}$ & $\begin{array}{c}\text { Pseudoscience } \\
\text { beliefs }\end{array}$ & $\begin{array}{c}\text { Paranormal } \\
\text { beliefs }\end{array}$ \\
\hline Order & -.05 & -.05 & -.03 \\
\hline Predictability & .05 & -.04 & -.01 \\
\hline Decisiveness & .09 & .06 & $.15^{\star \star}$ \\
\hline Ambiguity & -.09 & -.06 & -.01 \\
\hline Closed-mindedness & $.12^{\star \star}$ & $.20^{\star \star}$ & .04 \\
\hline $\mathbf{R}^{2}$ & .025 & .035 & .024 \\
\hline Note. ${ }^{*} p<=.05,{ }^{* \star} p<=.01$ & & & \\
\hline
\end{tabular}

\section{Conclusion}

- The results support the hypothesis that the cognitive motivation can contribute to the acceptance of epistemically unwarranted beliefs, however, effect sizes are rather small.

- As need for closure was found to be a predictor of all types of unwarranted beliefs, it seems that especially cognitive preference for a quick answer on a given topic and closedmindendess promote acceptance of such beliefs.

\section{References}

- Lobato, E., et al. (2014). Examining the relationship between conspiracy theories, paranormal beliefs, and pseudoscience Psychology, 28(5), 617-625.

Swami, V. ,et al. (2014). Analytic thinking reduces belief in conspiracy theories. Cognition, 133(3), 572-585.

- Neuberg, S. L., \& Newsom, J. T. (1993). Personal need for structure: Individual differences in the desire for simpler structure. Journal of Personality and Social Psychology, 65(1),

Roets, A., \& Van Hiel, A. (2011). Item selection and validation Scale. Personality and Individual Differences, 50(1), 90-94.

- Halama, P. (2018) Construction and psychometric properties of The Epistemologically Unfounded Beliefs Scale. Presented at the Conference on Social Processes and Personality, Stara lesna, Slovakia, 17.-19.9.2018.

de Holanda Coelho, G. L., Hanel, P. H. P., \& Wolf, L. J. (in press). The Very Efficient Assessment of Need for Cognition: Developing a Six-Item Version. Assessment.

\section{Acknowledgements}

Supported by the grant agency APVV under the contract No. APVV 6-0153 